\title{
PENGARUH ETOS KERJA ISLAM TERHADAP KOMITMEN KERJA KARYAWAN YAYASAN PONDOK PESANTREN HIDAYATULLAH SURABAYA
}

\author{
Novandi Arif Pratama \\ Mahasiswa Program Studi S1 Ekonomi Islam - Fakultas Ekonomi dan Bisnis, Universitas \\ Airlangga \\ Email: nova.pratama@gmail.com \\ Ari Prasetyo, SE., M.Si \\ Departemen Ekonomi Syariah - Fakultas Ekonomi dan Bisnis - Universitas Airlangga \\ Email: ariffeunair@yahoo.co.id
}

\begin{abstract}
:
This research was aimed to investigate the effect of Islamic work ethics to the organizational commitment on Yayasan Pondok Pesantren Hidayatullah in Surabaya. This study used questionnaires in primary data collection and quantitative approaches. Experiments were done using simple linear regression, where the dependent variable $(Y)$ is the organizational commitment and the independent variable $(X)$ is Islamic work ethics. The research sample were taken by nonprobability sampling with purposive sampling method. The research sample was 58 employees work in Yayasan Pondok Pesantren Hidayatullah Surabaya

Based on the findings, it obtained simple linear regression equation : $Y=5,908+$ $0,452 X$. The magnitude of the influence of Islamic work ethics to the organizational commitment on Yayasan Pondok Pesantren Hidayatullah Surabaya.

According to the final summaries of description data analysis from Islamic work ethic variable, that is have a resolute stand and got no effect (X1.3) has the lowest mean value, Yayasan Pondok Pesantren Hidayatullah be expected to capable of keeping and increasing the human resources, in shaping employees resolute and not easily influenced, so as to improve the islamic work ethic. For the next research can be done with distinguish the permanent employees and not-permanent employees which later result from the study will be compared to find out the influence of Islamic work ethic to deeper Organizational commitment.
\end{abstract}

\section{Keywords : Islamic Work Ethics, Organizational Commitment}

\section{PENDAHULUAN}

\section{Latar Belakang Masalah}

Pada era modern saat ini, sumber informasi sudah sangat cepat penyebarannya dengan menggunakan teknologi yang canggih, peranan teknologi informasi yang begitu besar tidak dapat begitu saja mengabaikan fungsi sumber daya insani, karena manusia berperan penting dalam menjalankan sumber daya lain yang dimiliki oleh organisasi/instansi. Hadirnya manusia di dalam organisasi/instansi memiliki posisi yang sangat penting. Manusia dipandang sebagai salah satu sumber daya, dimana manusia merupakan faktor penggerak dari sumber daya lain misalnya sumber daya alam atau teknologi dari suatu organisasi/instansi. Keberhasilan suatu organisasi baik besar maupun kecil bukan semata-mata ditentukan oleh sumber 
daya alam atau teknologi yang tersedia, akan tetapi banyak ditentukan oleh kualitas sumber daya manusia yang berperan, dalam merencanakan, melaksanakan dan mengendalikan organisasi (Manullang 2005).

Pendekatan dalam upaya peningkatan kualitas sumber daya manusia dapat dilakukan melalui pendekatan psikologis dan organisasi, budaya serta agama. Menurut Mangkunegara (2005:04) bahwa dalam hubungan dengan pencapaian kerja individu dan organisasi di era globalisasi perlu dilandaskan pendekatan psikologi dan organisasi, pendekatan budaya serta agama. Peran sumber daya manusia dalam memajukan suatu perusahaan sangatlah penting. Salah satu pendekatan dalam peningkatan kualitas sumber daya manusia adalah melalui pendekatan agama. Dalam agama Islam terdapat konsep etos kerja Islami yang berlandaskan Al Quran serta contoh dari Nabi Muhammad SAW.

Menurut Ali dan Owaihan dalam Marsalia (2008:02) sejak awal masa muslim, khususnya umat muslim telah menawarkan pandangan pada pekerjaan dan telah merumuskan secara jelas mengenai konsep etos kerja. Ełos kerja erat kaitannya dengan nilai-nilai kerja yang diyakini dan dimiliki oleh seorang karyawan, yang nantinya mempengaruhi sikap karyawan dalam bekerja. Manusia adalah suatu makhluk yang diarahkan dan terpengaruh suatu keyakinan yang mengikatnya, salah atau benar keyakinan tersebut niscaya mempengaruhi perilaku orang bersangkutan (Nuwair dalam Asifudin, 2004:30).

Etos kerja Islam yang memiliki karakteristik yang dapat dijadikan dimensi dalam mempengaruhi komitmen kerja atau komitmen organisasi suatu karyawan. Etos kerja Islam atau karakter atau kebiasaan karyawan yang bersumber dari dari keyakinan atau syariat Islam dan dilandasi pada AI Quran dan sunnah akan memberikan motivasi besar kepada dirinya untuk memberikan suatu komitmen pada suatu organisasi atau perusahaan.

Menurut Robbins (2001) pengertian komitmen kerja terhadap organisasi adalah suatu keadaan dimana seorang karyawan memihak pada suatu organisasi tertentu dan tujuan-tujuannya, serta memelihara keanggotaan dalam organisasi itu. Pemihakan ini disebabkan adanya keterlibatan kerja yang tinggi pada pekerjaannya yang berarti sekaligus memihak terhadap organisasi yang mempekerjakannya. Disamping hal tersebut komitmen juga dipandang sebagai suatu keadaan dimana sesorang individu memihak organisasi serta tujuantujuan dan keinginannya untuk mempertahankan keanggotaanya dalam organisasi (Robbins dan Judge, 2007:145). Sedangkan O'Reilly dalam Poerwati, dkk (2002) menyatakan bahwa komitmen kerja terhadap organisasi secara umum dipahami sebagai ikatan kejiwaan individu terhadap organisasi termasuk 
keterlibatan kerja, kesetiaan dan perasaan percaya pada nilai-nilai organisasi.

Berdasarkan beberapa definisi ini, dalam komitmen kerja tercakup unsur loyalitas terhadap perusahaan, keterlibatan dalam pekerjaan, dan identifikasi terhadap nilai-nilai dan tujuan perusahaan. Maka pada intinya beberapa definisi komitmen organisasi dari beberapa ahli diatas mempunyai penekanan yang hampir sama yaitu proses pada individu karyawan dalam mengidentifikasi dirinya dengan nilai-nilai, aturan-aturan, dan tujuan organisasi.

Organisasi/instansi yang menerapkan ajaran Islam secara kaffah memiliki tujuan berdimensi dunia dan akhirat.organisasi tersebut tidak hanya berfokus pada pencapaian keuntungan dunia berupa materi namun diiringi dengan berusaha untuk mencapai ridha Allah SWT. Salah satu organisasi/instansi yang memiliki tujuan berdimensi dunia dan akhirat adalah Yayasan Pondok Pesantren Hidayatullah Surabaya. Yayasan Pondok Pesantren Hidayatullah Surabaya hadir dengan mencetak murid-murid yang berprestasi, hal ini dibuktikan dengan diraihnya juara III National English Olympiade On Elementary School Level 2013 dan juara III Lomba Business Information System. Selain itu Yayasan Pondok Pesantren meraih juara I Eco Pesantren Se-Kota Surabaya dan untuk SMA Luqman Al-Hakim Surabaya sudah mendapatkan Akreditasi "A". Hasil prestasi yang telah diraih oleh Yayasan Pondok
Pesantren Hidayatullah Surabaya merupakan hasil kerja keras para guru dan karyawan.

$$
\text { Menurut Moelyadi }
$$

menunjukkan bahwa Etos kerja Islam memilik pengaruh yang positif terhadap komitmen kerja. Prestasi yang diperoleh Yayasan Pondok Pesantren Hidayatullah Surabaya bisa dijadikan tolak ukur dalam penilaian komitmen kerja karyawannya.

Berdasarkan latar belakang diatas, penelitian ini dibuat untuk melihat pengaruh antara etos kerja Islami terhadap komitmen kerja karyawan Pondok Pesantren Hidayatullah, Maka judul dari penulisan penelitian ini adalah Pengaruh Ełos Kerja Islam Terhadap Komitmen Kerja Karyawan Yayasan Pondok Pesantren Hidayatullah Surabaya.

\section{Rumusan Masalah}

Berdasarkan uraian pada latar belakang diatas, maka dapat dirumuskan bahwa masalah yang ingin diteliti adalah apakah Ełos Kerja Islam memiliki pengaruh secara signifikan terhadap komitmen kerja yayasan pondok pesantren hidayattullah Surabaya?

\section{Tujuan Penelitian}

Berdasarkan latar belakang serta rumusan masalah yang dikemukakan diatas maka dapat disebutkan bahwa tujuan penelitian ini adalah untuk mengetahui apakah terdapat pengaruh signifikan antara etos kerja Islami terhadap komitmen kerja karyawan yayasan pondok pesantren hidayatullah Surabaya. 
II. KAJIAN PUSTAKA DAN PENGEMBANGAN HIPOTESIS

Etos Kerja

Menurut Sinamo (2005:5), etos kerja adalah seperangkat perilaku positif yang berakar pada keyakinan fundamental yang disertai komitmen total pada paradigma kerja yang integral. Menurutnya, jika seseorang, suatu organisasi, atau suatu komunitas menganut paradigma kerja, mempercayai, dan berkomitmen pada paradigma kerja tersebut, semua itu akan melahirkan sikap dan perilaku kerja mereka yang khas, itulah yang akan menjadi budaya kerja.

\section{Ełos Kerja Islam}

Menurut Asifudin (2004:234) merupakan karakter dan kebiasaan manusia berkenaan dengan kerja, terpancar dari sistem keimanan/aqidah Islam yang merupakan sikap hidup mendasar terhadapnya. Ełos kerja Islami adalah akhlak dalam bekerja sesuai dengan nilai-nilai Islam sehingga dalam melaksanakannya tidak perlu lagi di pikirpikir karena jiwanya sudah meyakini sebagai sesuatu yang baik dan benar.

\section{Komitmen Kerja}

Mowday (dalam Sopiah, 2008:155) menyebut komitmen kerja sebagai istilah lain dari komitmen organisasional dan diartikan sebagai dimensi perilaku yang dapat digunakan untuk menilai kecenderungan karyawan untuk bertahan sebagai anggota organisasi.
Jenis komitmen karyawan terhadap perusahaan menurut Allen dan Meyer dalam Greenberg (2002:131-132) membedakan komitmen organisasi atas tiga dimensi, yaitu: continuance, affective, dan normative.

1. Continuance commitment yaitu keterikatan psikologis pada organisasi karena biaya yang di tanggung sebagai konsekuensi keluar organisasi. Greenberg (2002:131) menambahkan continuance commitment adalah tingkat individu untuk bekerja dalam suatu organisasi karena dia membutuhkan dan tidak dapat melakukan ditempat lain. Jenis komitmen ini nampaknya tergantung juga pada kondisi perekonomian. Seseorang dengan tingkat rendah pada jenis komitmen ini akan segera mempertimbangkan pekerjaan dimanapun bila perekonomian meningkat.

2. Normative commitment merupakan perasaan-perasaan karyawan tentang kewajiban yang harus ia berikan kepada organisasi. Greenberg (2002:67) memberikan gambaran atas pengertian komitmen ini dengan tingkat keinginan individu untuk terus bekerja dalam organisasi karena merasa ada tekanan dari pihak lain, jadi individu berada dalam suatu perusahaan karena adanya keharusan "should to" atau "ought to".

3. Affective commitement merupakan keterikatan secara psikologis dengan organisasi berdasarkan seberapa baik 
perasaan. Komitmen dalam jenis ini muncul dan berkembang oleh dorongan adanya kenyamanan, keamanan, dan manfaat lain yang dirasakan dalam suatu perusahaan yang tidak diperolehnya di tempat atau perusahaan lain semakin nyaman dan tinggi manfaat yang dirasakan oleh anggota maka semakin tinggi komitmen karyawan pada perusahaan. Sehingga definisi komitmen ini sebagai sesuatu yang merupakan refleksi atas "want to" dari individu kepada perusahaan.

Berdasarkan pada latar belakang masalah, rumusan masalah, tujuan penelitian, dan landasan teori, maka hipotesis yang akan digunakan dalam penelitian ini adalah Ełos kerja Islam memiliki pengaruh secara signifikan terhadap komitmen kerja karyawan pada Yayasan Pondok Pesantren Hidayatullah di Surabaya.

\section{Model Analisis}

Berdasarkan hipotesis di atas, maka dalam penelitian ini digunakan analisis dengan kerangka kerja penelitian untuk menjelaskan hubungan spesifik antara variabel eksogen dan variabel endogen. Model analisis dari penelitian ini adalah sebagai berikut:

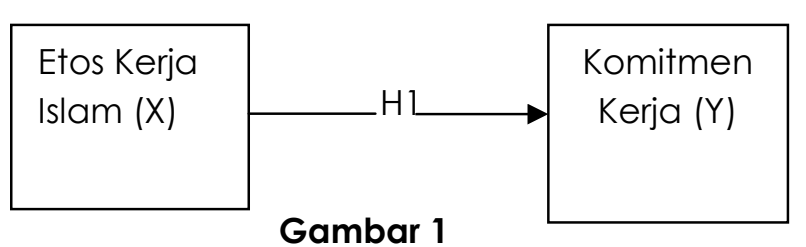

\section{METODE PENELITIAN}

Pendekatan penelitian yang digunakan dalam penelitian ini adalah pendekatan kuantitatif, yang bertujuan untuk menguji hipotesis, dengan data yang terukur dan menghasilkan kesimpulan yang dapat digeneralisir. Hermawan (2005:18) menjelaskan bahwa, penelitian kuantitatif adalah suatu pendekatan penelitian yang bersifat obyektif, mencakup pengumpulan dan analisis data kuantitatif serta menggunakan metode pengujian statistik.

Setelah data terkumpul, kemudian dianalisis dengan metode regresi linier sederhana (Simple Linear Regression Model). Model analisis ini dilakukan untuk mengetahui pengaruh atau hubungan variabel endogen (komitmen kerja) dan variabel eksogen (Ełos Kerja Islam).

Berdasarkan variabel-variabel yang digunakan, maka hubungan antar variabel dapat dinyatakan dalam fungsi sebagai berikut:

$Y=f(X)$

Bentuk persamaan regresi dapat dirumuskan sebagai berikut :

$Y=\beta_{0}+\beta_{1} X+\varepsilon$.

Keterangan:

$$
\begin{array}{ll}
\mathrm{Y} & =\text { Komitmen Kerja } \\
\mathrm{X} & =\text { Etos Kerja Islam } \\
\beta_{0} & =\text { Konstanta } \\
\beta_{1} & =\text { Koefisien Regresi } \\
\varepsilon & =\text { Variabel Error }
\end{array}
$$

Dari model analisa regresi linear yang digunakan, terdapat beberapa asumsi klasik yang dapat digunakan untuk mengestimasi hasil agar tidak ada 
penyimpangan sehingga dapat memberikan informasi yang sesuai dengan data yang tersedia. Asumsi klasik tersebut adalah, uji heteroskedastisitas, dan uji normalitas.

\section{Definisi Oprasional}

Variabel Eksogen ( $\mathrm{X}$ ) yaitu Etos Kerja Islam merupakan karakter dan kebiasaan manusia berkenaan dengan kerja, terpancar dari sistem keimanan atau aqidah Islam yang merupakan sikap hidup mendasar terhadapnya (Asifudin, 2004:234). Adapun indikator dan item-item dari variabel tingkat etos kerja Islam menurut Asifudin (2004:104) adalah :

a. Kerja merupakan penjabaran dari aqidah :

1) Dapat menerima kenyataan berkenaan dengan diri sendiri, orang lain, dan suasana kerja.

2) Berperilaku wajar tidak dibuat-buat

3) Berpendirian teguh dan tidak mudah terpengaruh

4) Konsentrasi perbuatan tidak pada ego, melainkan pada kewajiban

5) Memiliki rasa tanggung jawab dalam bekerja

6) Mempunyai kehidupan motivasi yang terutama digerakan oleh motivasi ibadah dan hasrat memperoleh kehidupan surgawi di akhirat kelak.

b. Kerja dilandasi ilmu :

1) Pernah atau sering mengalami pengalaman puncak

2) Mampu membedakan antara tujuan benar dan salah, baik dan buruk

3) Menyukai efisiensi dan efektivitas kerja
4) Mempunyai disiplin pribadi

c. Kerja dengan Meneladani Sifat-sifat Ilahi serta Mengikuti Petunjuk-petunjukNya :

1) Memiliki jiwa sosial dan sifat demokratis.

2) Mengembangkan kreativitas.

3) Percaya pada potensi insani karunia Tuhan untuk melaksanakan tugasnya: bertawakkal kepada Allah SWT.

4) Mengembangkan sikap hidup kritis konstruktif.

Variabel Endogen (Y) yaitu Komitmen Kerja merupakan kekuatan relatif dari suatu identifikasi individu dengan keterlibatan individu dalam organisasi. Mowday (dalam Sopiah, 2008:155) menyebut komitmen kerja sebagai istilah lain dari komitmen organisasional dan diartikan sebagai dimensi perilaku yang dapat digunakan untuk menilai kecenderungan karyawan untuk bertahan sebagai anggota organisasi. Komitmen organisasional menunjukkan sejauh mana seseorang memihak sebuah orhganisasi serta tujuantujuannya dan keinginan untuk mempertahankan keanggotaan dalam organisasi tersebut (Sunyoto, 2013:53).

Pengukuran komitmen kerja dalam penelitian ini akan menggunakan jenis komitmen kerja dari Allan dan Meyer dalam Toriqul (2013:62), yang telah disesuaikan dengan keadaan karyawan Yayasan Pondok pesantren Hidayatullah Surabaya yaitu :

a. Komitmen afektif, keterkaitan karyawan secara emosional, identifikasi 
dengan organisasi serta keterlibatan karyawan pada suatu perusahaan tertentu. Indikatornya meliputi

1) Perasaan senang bekerja pada Yayasan Pondok Pesantren Hidayatullah.

2) Perasaan merasa bahwa masalah Yayasan Pondok Pesantren Hidayatullah. juga merupakan masalah karyawan

3) Arti penting Yayasan Pondok Pesantren Hidayatullah bagi karyawan

4) Perasaan bangga menjadi anggota Yayasan Pondok Pesantren Hidayatullah.

b. Komitmen berkelanjutan, komitmen karyawan dengan pertimbangan kerugian apabila keluar dari organisasi. Indikatornya meliputi:

1) Karyawan ingin terus bekerja dalam Yayasan Pondok Pesantren Hidayatullah karena takut tidak mendapat pekerjaan di tempat lain

2) Karyawan tidak ingin meninggalkan Yayasan Pondok Pesantren Hidayatullah karena telah melakukan banyak hal untuk Yayasan Pondok Pesantren Hidayatullah.

3) Karyawan merasa rugi meninggalkan Yayasan Pondok Pesantren Hidayatullah, karena Yayasan Pondok Pesantren Hidayatullah telah memberikan apa yang di butuhkan.

c. Komitmen normatif, komitmen karyawan pada organisasi yang mengacu pada perasaan seseorang akan kewajiban untuk tinggal dalam suatu organisasi. Indikator meliputi:

1) Karyawan merasa mempunyai kewajiban untuk setia pada Yayasan Pondok Pesantren Hidayatullah.yang telah memberi penghidupan.

2) Karyawan tidak ingin meninggalkan Yayasan Pondok Pesantren Hidayatullah, karena merasa apa yang telah diberikan Yayasan Pondok Pesantren Hidayatullah sesuai harapan.

3) Karyawan bersedia bekerja lembur untuk dapat menyelesaikan pekerjaan yang diberikan oleh Yayasan Pondok Pesantren Hidayatullah.

\section{Populasi}

Populasi adalah kumpulan individu dengan kualitas serta ciri-ciri yang sebelumnya sudah ditetapkan (Nazir dalam Anshori dan Iswati, 2009:92). Sugiyono (2010:117) menjelaskan bahwa, populasi adalah wilayah generalisasi yang terdiri atas: obyek/subyek yang mempunyai kualitas dan karakteristik tertentu yang ditetapkan oleh peneliti untuk dipelajari dan kemudian ditarik kesimpulan. Populasi dalam penelitian ini adalah karyawan Yayasan Pondok Pesantren Hidayatullah Surabaya yang bekerja lebih dari 3 tahun. 
IV. HASIL PENELITIAN DAN PEMBAHASAN Uji Normalitas

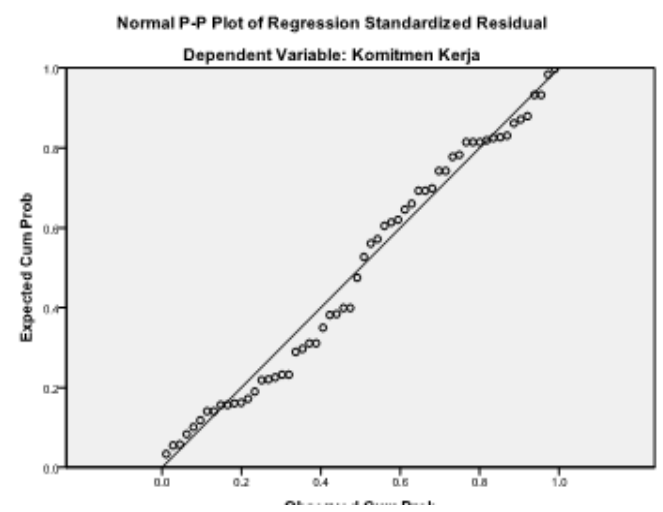

Gambar 2

menunjukkan bahwa titik-titik menyebar secara teratur di sekitar garis lurus melintang, sehingga dapat dinyatakan bahwa data yang digunakan adalah normal (Yamin dan Kurniawan, 2009:90)

Hasil Uji Regresi Linear Sederhana

Tabel 1

\begin{tabular}{|l|c|c|c|c|}
\hline \multirow{2}{*}{ Variabel } & \multicolumn{2}{|c|}{ Koefisien } & \multirow{2}{*}{ hit. } & Sign. \\
\cline { 2 - 3 } & $\begin{array}{c}\text { Koef. } \\
\text { Reg. }\end{array}$ & Beta & & \\
\hline Konstanta & 5,908 & & 0,955 & 0,344 \\
\hline $\begin{array}{l}\text { Etos Keria } \\
\text { Islam }\end{array}$ & 0,452 & 0,443 & 3,697 & 0,000 \\
\hline $\begin{array}{l}\text { Multiple R }=\mathbf{0 , 4 4 3} \\
\text { R Square }=\mathbf{0 , 1 9 6}\end{array}$ \\
$\mathbf{0 , 0 0 0}$
\end{tabular}

Berdasarkan hasil regresi sederhana, maka persamaan regresi yang dapat dibuat adalah sebagai berikut :

$$
Y=5,908+0,452 \times \ldots \ldots \ldots \text { (7) }
$$

Dimana $: Y=$ Komitmen Kerja

$$
\mathrm{X}=\text { Ełos Kerja Islam Islam }
$$

Koefisien regresi yang bertanda positif menunjukkan perubahan yang searah antara variabel bebas terhadap variabel tergantung. Penjelasan untuk persamaan tersebut adalah:
1. Jika tidak ada pengaruh dari variabel Etos Kerja Islam Islam dan yang lain dianggap konstan maka Komitmen Kerja adalah sebesar 5,908

2. Koefisien regresi Etos Kerja Islam Islam (X) sebesar 0,452, berarti jika variabel bebas yaitu Ełos Kerja Islam Islam ditingkatkan dan variabel lain dalam keadaan konstan maka Komitmen Kerja juga akan meningkat dengan koefisien regresi sebesar 0,452.

\section{Hasil Regresi}

\section{Tabel 2}

Iaver 4.11

\begin{tabular}{|c|c|c|}
\hline Variabel & $\mathrm{t}$ & Tingkat signifikansi \\
\hline Etos Kerja Islam & $\begin{array}{ll}3,697 \\
\end{array}$ & 0.000 \\
\hline
\end{tabular}

Hasil Uji Regresi Secara Parsial (Uji t)

Nilai uji † untuk variabel Ełos Kerja Islam Islam (X) adalah sebesar 3,697 dengan tingkat signifikasi 0,000 . Tingkat signifikasi uji $\dagger$ dalam penelitian ini sebesar 0,000 merupakan besaran signifikansi yang lebih kecil dari tingat signifikansi yang dijinkan (a) yaitu 0,05, sehingga dapat dinyatakan bahwa Ho ditolak yang berarti ada pengaruh secara parsial antara variabel Etos Kerja Islam Islam (X) terhadap variabel Komitmen Kerja karyawan Yayasan Pondok Pesantren Hidayatullah Surabaya (Y).

\section{Pembahasan}

Penelitian ini berfokus untuk mencari hubungan antara Ełos Kerja Islam Islam dengan Komitmen Kerja karyawan Yayasan Pondok Pesantren Hidayatullah Surabaya. Hasil penelitan menunjukan bahwa hipotesis penelitian terbukti kebenarannya, yaitu etos kerja islam 
memiliki pengaruh atau berpengaruh terhadap komitmen kerja pada karyawan Yayasan Pondok Pesantren Hidayatullah Surabaya. Berdasarkan pengujian regresi sederhana menunjukan besarnya pengaaruh etos kerja islam terhadap komitmen kerja besarnya $R$ square sebesar 0,196 (19,6\%).

Berdasarkan hasil analisi koefisien korelasi dalam penelitian ini, disebutkan bahwa variabel Ełos Kerja Islam Islam (X) berpengaruh signifikan dengan variabel Komitmen Kerja (Y). Hubungan antar variabel juga menunjukkan tanda positif. Hubungan yang positif antar variabel tersebut dapat diartikan bahwa setiap peningkatan variabel bebas akan berpengaruh terhadap peningkatan variabel tergantung, begitu pula sebaliknya setiap penurunan variabel bebas akan berpengaruh pula pada penurunan variabel tergantung.

Hasil uji regresi dengan menggunakan uji $t$ menunjukkan besar nilai $\dagger$ sebesar 3,697 dengan tingkat signifikan $\leq 0,05$, yaitu 0,000 . Hasil tersebut menunjukan bahwa tinggi rendahnya komitmen kerja karyawan Yayasan Pondok Pesantren Hidayatullah Surabaya salah satunya dipengaruhi oleh faktor etos kerja Islam. Dengan demikian, hasil analisis ini menunjukan bahwa hipotesis dapat diterima, artinya etos kerja Islam mempunyai pengaruh positif yang signifikan terhadap komitmen kerja karyawan Yayasan Pondok Pesantren Hidayatullah Surabaya.
Berdasarkan hasil pengolahan data dari 58 responden, menunjukan bahwa secara keseluruhan rata-rata tanggapan responden pada etos kerja Islam termasuk sangat tinggi dengan nilai mean variabel bebas sebesar 3,36, dan Sesuai dengan hasil analisis data deskripsi variabel etos kerja Islam yaitu berpendirian teguh dan tidak berpengaruh $\left(X_{1.3}\right)$ memiliki nilai mean terendah.

\section{SIMPULAN}

Berdasarkan hasil analisisi dan pengujian hipotesis pada bab sebelumnya maka dapat diambil kesimpulan bahwa variabel etos kerja Islam berpengaruh secara langsung, positif, dan signifikan terhadap komitmen kerja karyawan Yayasan Pondok Pesantren Hidayatullah Surabaya. Hal ini menujukan bahwa hipotesis dalam penelitian ini yang menyatakan bahwa variabel etos kerja Islam berpengaruh signifikan terhadap variabel komitmen kerja. Secara teoritis hasil penelitian ini mengandung makna bahwa Variabel etos kerja Islam merupakan salah satu intrumen penting untuk mempengaruhui komitmen kerja karyawan Yayasan Pondok Pesantren Hidayatullah Surabaya, karena semakin tinggi etos kerja Islam, maka akan semakin meningkat pula komitmen kerjannya.

\section{DAFTAR PUSTAKA}

Ahmad Janan Asifudin, 2004, Etos Kerja Islami, Muhammadiyah University Press, Surakarta. 
Akbar, Toriqul Hajjil. 2013. Pengaruh Gaya Kepemimpinan Islam Tehadap Komitmen Kerja Dan Pengaruhnya Terhadap Kepuasan Kerja Karyawan Pada Bank BNI Syariah Surabaya. Skripsi S1. Surabaya: Unair.

Alex S Nitisemito. 2001. Manajemen Personalia.Edisi kedua. Ghalia Indonesia.

Ali, J.A. and Al-Owaihan, A. 2008. "Islamic work ethic: a critical review" Cross Cultural Management an International Journal. Vol. 15 No. 1.

Anshori, Muslich dan Sri Iswati. 2009. Metodologi Penelitiian Kuantitatif. Surabaya: Airlangga University Press.

Greenberg, J. 2002. Behavior In Organization. Seventh Edition. New Jersey: Prentice Hall.

Hayati, Keumala. 2012. Islamic Work Ethic: The Role of Intrinsic Motivation, Job Satisfaction, Organizational Commitment and JobPerformance. Procedia - Social and Behavioral Sciences 65 ( 2012 ) $272-277$.

Indica, I Wayan Marsalia. 2013. Pengaruh Etos Kerja Islami dan Gaya Kepemimpinan Transformasional Terhadap Komitmen Organisasional dan Kinerja Karyawan.
Mangkunegara, Anwar Prabu. (2005). Perencanaan dan Pengembangan Sumberdaya Manusia. Bandung: PT. Refika Aditama.

Manullang, M. (2005) Dasar-dasar Manajemen. Yogyakarta : Gadjah Mada University Press.

Moelyadi, Naghmeh Nancy. 2009. Islamic Work Ethic And Muslim Religious Beliefs Impact On Organizational Commitment In The Workplace.

Poerwanti, E.S., Margono Setiawan \& Bambang Swasto. 2002. Pengaruh Kopensasi Terhadap Kerja dan Dampaknya pada Komitmen Karyawan pada Komitmen karyawan (Study pada PT Telekomunikasi Tbk. Kandatel Malang). Jurnal Ekonomi dan Bisnis. Vol. XXII, No.1. Hal 59-71.

Robbins, P Stephen, Handyana Pujaatmaka (Penterjemah). 2001. Perilaku Organisasi, Konsep, Kontroversi, Aplikasi, Jakarta : PT. Prenhallindo.

Robbins SP, dan Judge. 2007. Perilaku Organisasi, Salemba Empat, Jakarta.

Sinamo, Jansen. 2005. Delapan Ełos Kerja Profesional; Navigator Anda Menuju Sukses. Bogor: Grafika Mardi Yuana.

Sopiah. 2008. Perilaku Organisasional.

Yogyakarta : C.V Andi Offset. 
Sugiyono. 2010. Metode Penelitian Bisnis: Pendekatan Kuantitatif, Kualitatif, dan R\&D. Bandung: Alfabeta.

Yamin, Sofyan \& Kurniawan, Heri. 2009. SPPS Complete. Jakarta: Salemba Infotek. 